Jurnal Insan Farmasi Indonesia, 3(2) Desember 2020 (377-386)

Okta Muthia Sari

p-ISSN 2621-3184; e-ISSN 2621-4032

doi: $10.36387 /$ jifi.v3i2.574

\title{
EVALUASI PERESEPAN OBAT PASIEN RAWAT JALAN PUSKESMAS SUNGAI TABUK 1 KALIMANTAN SELATAN TERHADAP FORMULAIRUM KABUPATEN BANJAR
}

\author{
${ }^{1}$ Okta Muthia Sari, ${ }^{1}$ Rollah Muhammad Arasy Hasan, ${ }^{2}$ Pretty Wulan Sari, ${ }^{1}$ Henni \\ Selvina \\ ${ }^{1}$ Fakultas Matematika dan Ilmu Pengetahuan Alam Universitas Lambung \\ Mangkurat \\ ${ }^{2}$ Puskesmas Sungai Tabuk 1 Martapura Kalimantan Selatan \\ *:okta.sari@ulm.ac.id
}

\begin{abstract}
ABSTRAK
Formularium merupakan pedoman bagi tenaga kesehatan dalam memilih obat secara rasional. Manfaat formularium salah satunya yaitu untuk pengendalian mutu dan untuk mengoptimalkan pelayanan pada pasien. Kesesuaian peresepan obat terhadap formularium penting dilakukan sebagai konsekuensi peningkatan mutu pelayanan. Tujuan dari penelitian ini adalah untuk mengevaluasi kesesuaian peresepan obat di pelayanan kesehatan primer (Puskesmas) Sungai Tabuk 1 terhadap Formularium Kabupaten Banjar periode 2019. Penelitian deskriptif retrospektif ini dilakukan pada bulan Januari sampai Februari 2020 di poli umum rawat jalan Puskesmas Sungai Tabuk 1 Kalimantan Selatan. Peresepan obat di rawat jalan dari 16 kelas terapi terdapat 13 kelas terapi yang $100 \%$ sesuai terhadap Formularium Kabupaten Banjar. Sedangkan 3 kelas terapi kesesuaiannya kurang dari $100 \%$ diantaranya antiinfeksi, obat topikal untuk kulit serta vitamin dan mineral. Adapun persentase rerata peresepan obat di Puskesmas Sungai Tabuk 1 yang sesuai dengan Formularium Kabupaten Banjar sebesar 99,15.
\end{abstract}

Kata Kunci: Kesesuaian Peresepan; Formularium

\section{ABSTRACT}

Drug formularies are a guide for health workers in choosing drugs rationally. One of the benefits of formularies is controlling quality and optimizing services for patients. The conformity of prescription drugs to formularies is important to improve the quality of service. The purpose of this study was to assess the conformity of prescription drugs at Sungai Tabuk 1 Primary Health Care against the Banjar District Formulary for the period 2019. This retrospective descriptive study was conducted in January to February 2020 at the outpatient of Sungai Tabuk 1 Primary Health, South Kalimantan. Prescribing drugs at the outpatient of the 16 therapy classes, there are 13 therapy classes 100\% according to the Banjar Regency Formulary. Meanwhile, 3 classes of less than 100\% conformity therapy include anti-infection, topical medicines for the skin, and vitamins and minerals. The mean percentage of prescription drugs at the outpatient of Sungai Tabuk 1 in accordance with the Banjar Regency Formulary was 99.15.

Keywords: prescribing conformity; formulary

PENDAHULUAN

Pusat Kesehatan Masyarakat (Puskesmas) merupakan fasilitas 
Okta Muthia Sari

p-ISSN 2621-3184 ; e-ISSN 2621-4032

doi: 10.36387/jifi.v3i2.574

pelayanan kesehatan dalam upaya digunakan di Puskesmas ${ }^{12}$. Formularium

kesehatan masyarakat ${ }^{1}$. Pelayanan Kabupaten dapat meningkatkan mutu kefarmasian merupakan salah satu pelayanan kesehatan yang diberikan di Puskesmas $^{2}$

Pelayanan kefarmasian dilakukan untuk meningkatkan mutu pelayanan dan keselamatan pasien ${ }^{3}$. Peningkatan mutu pelayanan kesehatan dapat dilakukan dengan menjamin aksesibilitas obat yang aman, berkhasiat, bermutu dan terjangkau ${ }^{4,5}$. Formularium merupakan upaya dalam meningkatkan dan mengendalikan mutu penggunaan obat sehingga pelayanan pada pasien menjadi optimal ${ }^{6,7,8}$.

$$
\text { Pelayanan resep dengan }
$$
mengacu pada formularium diharapkan dapat membantu dalam meningkatkan penggunaan obat yang rasional sehingga pasien memperoleh obat sesuai dengan kebutuhan klinisnya ${ }^{9,10,11}$. Berdasarkan penelitian oleh Pratiwi et al. (2017), semakin tinggi kesesuaian resep dengan formularium maka mutu pelayanan instalasi farmasi semakin baik ${ }^{10}$

Formularium Kabupaten merupakan daftar obat yang diterima serta disetujui oleh Tim Penyusun Formularium Kabupaten untuk penggunaan obat karena obat dalam Formularium Kabupaten telah diseleksi berdasarkan pertimbangan manfaat, keamanan, berdasarkan bukti ilmiah terkini, dan dengan harga yang terjangkau ${ }^{4}$..

Dinas kesehatan Kabupaten Banjar Kalimantan Selatan telah menyusun buku Formularium Kabupaten Banjar agar dapat digunakan sebagai pedoman dalam pemilihan obat secara rasional di Puskesmas ${ }^{12}$. Puskesmas Sungai Tabuk 1 merupakan pelayanan kesehatan tingkat pertama di wilayah kabupaten Banjar Kalimantan Selatan dan menggunakan Formularium Kabupaten dalam pelayanan obat pasien.

Beberapa penelitian di Indonesia menunjukkan kesesuaian peresepan obat di pelayanan kesehatan terhadap formularium berdasarkan persentase rerata beragam yakni berkisar 80 sampai $99,44^{10,13,14,15}$. Adapun pengkajian terkait kesesuaian peresepan obat di Puskesmas Sungai Tabuk 1 terhadap Formularium Kabupaten Banjar Kalimantan Selatan belum pernah dilakukan sebelumnya. Oleh sebab itu 
Okta Muthia Sari

p-ISSN 2621-3184; e-ISSN 2621-4032

doi: 10.36387/jifi.v3i2.574

perlu dilakukan penelitian terkait kesesuaian peresepan obat terhadap Formularium. Harapannya untuk membantu dalam meningkatkan dan menjamin mutu pelayanan kesehatan di Puskesmas sehingga aksesibilitas obat oleh pasien dapat tercapai maksimal. Adapun tujuan penelitian ini untuk mengevaluasi kesesuaian peresepan obat rawat jalan di Puskesmas Sungai Tabuk 1 terhadap Formularium Kabupaten Banjar.

\section{METODE PENELITIAN}

Penelitian deskriptif retrospektif ini dilakukan pada bulan Januari sampai Februari 2020 di rawat jalan poli umum Puskesmas Sungai Tabuk 1 Banjar. Instrumen penelitian ini yakni lembar pengumpul data, lembar resep rawat jalan dan buku Formularium Kabupaten Banjar Periode 2019.

Pengambilan sampel dilakukan dengan metode quota sampling secara acak. Sampel size dalam penelitian ini diperoleh dengan rumus Slovin, dengan taraf kepercayaan 95\%. Adapun lembar resep pasien rawat jalan pada bulan Maret, Juli dan September tahun 2019 adalah 1558 resep. Dengan demikian diperoleh sampel size sebesar 320 resep.
Jumlah sampel resep yang diambil per bulan diperoleh dengan cara membandingkan antara jumlah resep per bulan dengan populasi dikalikan dengan total sampel yang diambil, sehingga diperoleh jumlah sampel minimal yang diperlukan per bulan.

Kriteria inklusi dalam penelitian ini adalah resep pasien rawat jalan poli umum di Puskesmas Sungai Tabuk pada bulan Maret, Juli dan September 2019; serta resep yang tercantum identitas pasien, tanggal penulisan resep, nama obat dan kekuatan sediaan obat. Adapun kriteria ekslusi pada penelitian ini adalah resep yang tidak ditemukan atau hilang.

Pengumpulan data dilakukan yakni dengan mengumpulkan data dari resep yang selanjutnya dituliskan pada lembar pengumpul data. Pertimbangan pengambilan data pada bulan tersebut yaitu sebagai perwakilan peresepan per 4 bulan serta berdasarkan bulan dengan kuantitas resep terbanyak pada tahun 2019. Data yang sudah terkumpul diinput pada Microsoft Excel dan dilakukan pengolahan data serta selanjutnya dilakukan analisis data berdasarkan persentase. Kesesuaian peresepan dalam penelitian ini melihat 
Jurnal Insan Farmasi Indonesia, 3(2) Desember 2020 (377-386)

Okta Muthia Sari

p-ISSN 2621-3184; e-ISSN 2621-4032

doi: 10.36387/jifi.v3i2.574

dari aspek kelas terapi obat pada resep dengan Formularium Kabupaten Banjar.

Peresepan dikatakan sesuai apabila obat yang dituliskan oleh dokter di dalam resep, tercantum dalam Formularium Kabupaten.

\section{PEMBAHASAN}

Jumlah sampel yang diperoleh dalam penelitian ini yakni 320 resep yang memenuhi kriteria. Kesesuaian peresepan ditinjau berdasarkan aspek kelas terapi. Hal ini bertujuan untuk melihat sebaran kesesuaian peresepan untuk masing-masing kelas terapi, sehingga dapat diketahui kelas terapi yang paling sering mengalami ketidaksesuaian peresepan.

Hasil penelitian memperlihatkan dari 16 kelas terapi terdapat 13 kelas terapi yang kesesuaiannya 100\% yakni analgesik, antipiretik, antiinflamasi non steroid dan antipirai; antialergi dan obat untuk anafilaksis; antimigrain dan antivertigo; hormon dan obat endokrin lain; larutan elektrolit, nutrisi dan lainlain; obat kardiovaskular; obat penunjang; obat untuk mata; obat untuk saluran cerna; obat untuk saluran nafas; obat yang mempengaruhi darah; diuretik

dan obat hipertrofi prostat; serta obat untuk telinga, hidung dan tenggorokan. Namun terdapat 3 kelas terapi yang kesesuaiannya kurang dari 100\% yakni antiinfeksi $(97,53 \%)$, obat topikal untuk kulit $(97,22 \%)$ serta vitamin dan mineral (95,93\%). Data ini secara lengkap bisa dilihat pada tabel 1 .

Penelitian Arfania \& Ernawati tahun 2020 yang fokus pada peresepan obat-obat kardiovaskular, memperlihatkan sebesar $\quad 71,32 \%$ penulisan resep sesuai dengan formularium rumah sakit ${ }^{16}$. Hasil penelitian tersebut lebih rendah dibandingkan hasil penelitian ini untuk persentase kesesuaian peresepan obat kardiovaskular. Hal ini kemungkinan dipengaruhi beberapa faktor dalam penulisan resep oleh dokter.

Penelitian oleh Prihandiwati et al. (2018), menunjukkan hasil yang serupa dengan penelitian ini. Kesesuaian peresepan obat di rumah sakit dengan Formularium Nasional yakni dari 15 kelas terapi terdapat 11 kelas terapi yang kesesuaiannya $100 \%$ dan 4 kelas terapi yang kesesuaiannya kurang dari 100\%. Adapun kelas terapi yang kesesuaiannya kurang dari 100\% yakni analgesik, 
Jurnal Insan Farmasi Indonesia, 3(2) Desember 2020 (377-386)

Okta Muthia Sari

p-ISSN 2621-3184 ; e-ISSN 2621-4032

doi: 10.36387/jifi.v3i2.574

antipiretik, antiinflamasi non steroid dan antipirai; antiinfeksi; obat untuk saluran nafas; serta vitamin dan mineral ${ }^{15}$. Sedangkan penelitian di Puskesmas Kabupaten Tanggerang diketahui bahwa kesesuaian peresepan obat terhadap Formularium Nasional sudah mencapai $100 \%$ untuk semua kelas terapinya ${ }^{14}$. Hal ini menunjukkan kesesuaian peresepan obat terhadap formularium berdasarkan kelas terapi beragam, dimana dapat disebabkan oleh beberapa faktor.

Penelitian ini memperlihatkan peresepan obat rawat jalan poli umum Puskesmas Sungai Tabuk 1 pada bulan Maret, Juli dan September 2019 rataratanya sebesar 99,15\% (936 item obat) sesuai dengan Formularium Kabupaten Banjar 2019. Hal ini dapat dilihat pada tabel 2. Beberapa penelitian menunjukkan persentase rerata kesesuaian peresepan obat di Rumah Sakit dengan Formularium Nasional berkisar 79,6 sampai $99,44^{10,13,15}$. Adapun penelitian oleh Lestari et al. (2019), diketahui bahwa rereata persentase kesesuaian peresepan obat di

Puskesmas Kabupaten Tanggerang terhadap Formularium Nasional sebesar kurang lebih $80^{14}$. Hal ini menunjukkan kesesuaian peresepan obat terhadap formularium berdasarkan persentase rerata beragam.

Berdasarkan hasil penelitian item obat yang tidak sesuai dengan Formularium Kabupaten Banjar yakni obat MDT-MB ${ }^{\circledR}$, salep 3-6, hemoviton ${ }^{\circledR}$ dan livron B-PLex ${ }^{\circledR}$. Data ini secara lengkap bisa dilihat pada tabel 2. Obat MDT-MB ${ }^{\circledR}$ merupakan obat multi drugs therapy untuk kusta tipe Multibacillary Leprosy (MB). Obat ini terdiri dari kombinasi rifampisin, dapson dan clofazamin ${ }^{17}$. Obat MDT-MB ${ }^{\circledR}$ termasuk dalam obat program dari dinas kesehatan kabupaten Banjar. Namun obat ini belum masuk dalam formularium kabupaten Banjar. Adapun salep 3-6 merupakan obat skabies yang terdiri dari kombinasi asam salisilat $3 \%$ dan sulfur $6 \%{ }^{18}$. Obat skabies yang tercantum dalam formularium kabupaten Banjar yakni salep 2-4 yang merupakan kombinasi asam salisilat $2 \%$ dan sulfur $4 \%$. 
Jurnal Insan Farmasi Indonesia, 3(2) Desember 2020 (377-386)

Okta Muthia Sari

p-ISSN 2621-3184 ; e-ISSN 2621-4032

doi: 10.36387/jifi.v3i2.574

Tabel 1. Data Kesesuaian Kelas Terapi Peresepan

Rawat Jalan Puskesmas Sungai Tabuk 1 dengan

Formularium Kabupaten Banjar

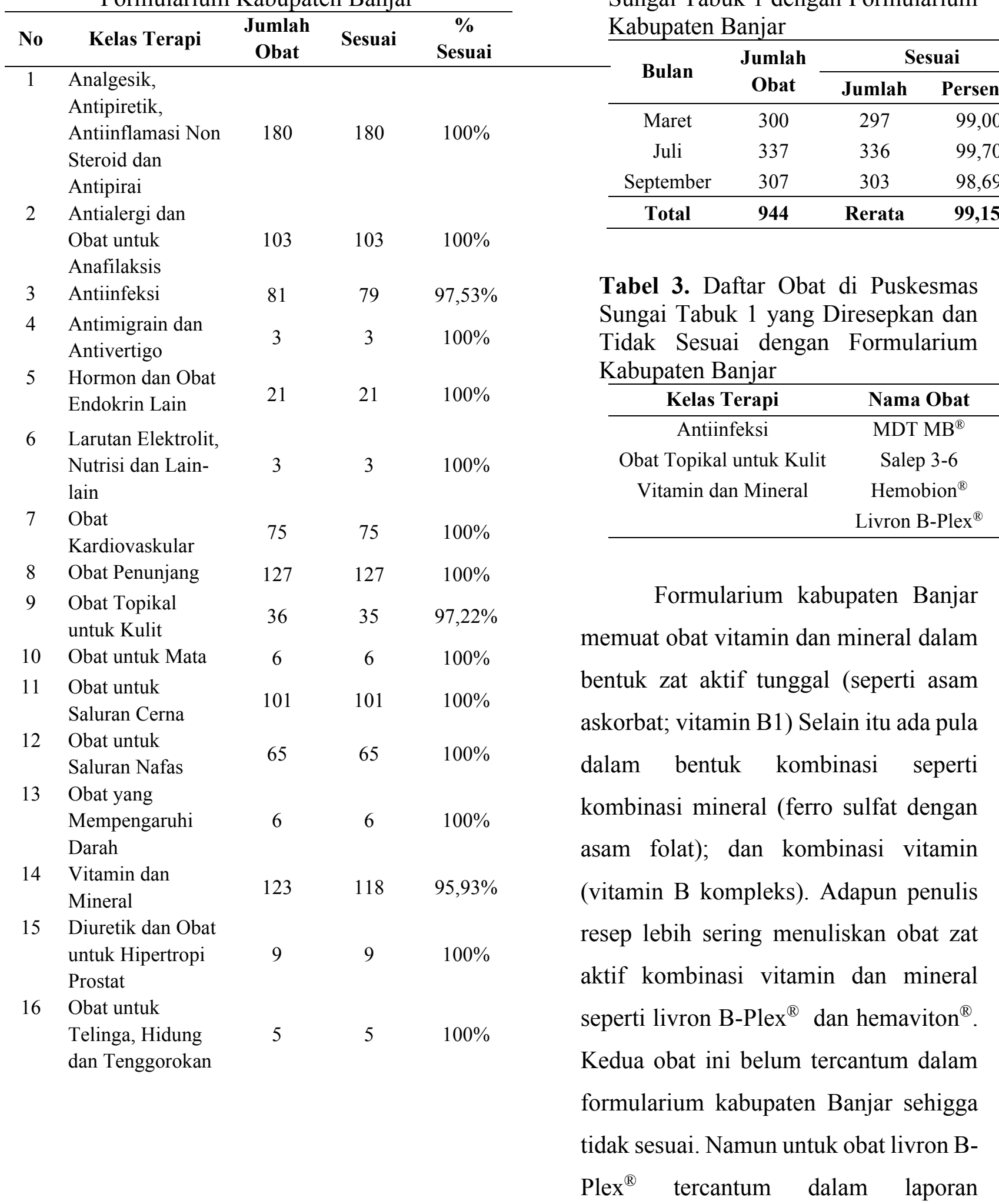


Jurnal Insan Farmasi Indonesia, 3(2) Desember 2020 (377-386)

Okta Muthia Sari

p-ISSN 2621-3184 ; e-ISSN 2621-4032

doi: 10.36387/jifi.v3i2.574

pemakaian dan lembar permintaan obat

(LPLPO) Puskesmas. Hal ini

menunjukkan antara formularium

kabupaten dengan LPLPO Puskesmas

belum tersinkronisasi.

Berdasarkan informasi dari Apoteker Penanggung Jawab Puskesmas Sungai Tabuk 1 diketahui kemungkinan terdapat beberapa faktor yang menyebabkan ketidaksesuaian obat yang diresepkan dengan Formularium Kabupaten. Apoteker Penanggung Jawab, Pretty Wulan Sari, memaparkan "Faktor ketidaksesuaian obat yang diresepkan disebabkan obat yang diresepkan tidak termasuk ke dalam formularium karena merupakan obat program dari dinas kesehatan kabupaten Banjar". Lebih lanjut Apoteker Penanggung Jawab, Pretty Wulan Sari, mengatakan bahwa "Faktor lainnya yaitu adanya ketidaksesuaian antara formularium kabupaten dengan form LPLPO; dan terakhir faktor individu dokter tersebut seperti pengalaman dokter dalam menuliskan resep".

Menurut World Health Organization dalam Pratiwi et al. (2017), faktor yang menyebabkan ketidaksesuaian penulisan resep terdiri berkaitan dengan kondisi pasien, dan faktor non medis, yaitu faktor yang berkaitan dengan individu dokter (10). Beberapa penelitian di Indonesia menjelaskan bahwa ada beberapa alasan yang menyebabkan ketidaksesuaian peresepan dengan formularium. Alasannya yakni dokter menuliskan resep obat dengan nama merek dagang; pasien dalam keadaan darurat atau tidak dapat menerima obat sesuai formularium; tanggung jawab personal; dukungan rekan; kedekatan figur otoritas; dan permintaan dari pasien untuk meresepkan obat tertentu serta faktor ketersediaan obat 10,13-15,19,20.

Rerata kesesuaian peresepan obat di poli umum Puskesmas Sungai Tabuk 1 terhadap Formularium Kabupaten Banjar periode 2019 sebesar $99,15 \%$ sesuai dan $0,85 \%$ tidak sesuai. Dampak dari ketidaksesuaian resep dengan formularium bagi pasien adalah kemungkinan pasien tidak bisa mendapatkan obat yang tertulis di resep karena ketidaktersediaan obat di fasilitas kesehatan tersebut, sehingga pasien gagal mendapatkan terapi (21). Selain itu penulisan resep tidak sesuai formularium 
Jurnal Insan Farmasi Indonesia, 3(2) Desember 2020 (377-386)

Okta Muthia Sari

p-ISSN 2621-3184 ; e-ISSN 2621-4032

doi: 10.36387/jifi.v3i2.574

dapat memperngaruhi persediaan obat yang akan memicu terjadinya kekurangan atau kekosongan obat (22).

Berdasarkan Standar Teknis

Pemenuhan Mutu Pelayanan Dasar tahun 2019, setiap jenis pelayanan dasar pada Standar Pelayanan Minimal (SPM) bidang kesehatan harus $100 \%{ }^{23}$. Hasil penelitian ini memperlihatkan kesesuaian peresepan berdasarkan Formularium Kabupaten belum memenuhi standar ${ }^{23}$. Permasalahan ketidaksesuaian dapat ditindaklanjuti dengan melakukan sosialisasi atau pemberian informasi secara berkala kepada tenaga kesehatan di Puskesmas Sungai Tabuk 1 tentang daftar obat yang tersedia di apotek serta dengan melakukan penyesuaian antara Formularium Kabupaten dengan laporan pemakaian dan lembar permintaan obat (LPLPO) di Puskesmas. Berdasarkan penelitian, pengetahuan atau pemberian informasi berpengaruh secara signifikan dalam penulisan resep sesuai dengan formularium $^{24}$.

Selama proses pengumpulan dan analisis data ditemukan juga ketidaksesuaian antara peresepan dengan Formularium Kabupaten

berdasarkan kekuatan sediaannya. Hal ini dapat dikaji lebih lanjut untuk penelitian selanjutnya.

\section{KESIMPULAN}

Peresepan obat di rawat jalan Puskesmas Sungai Tabuk 1 dari 16 kelas terapi terdapat 13 kelas terapi yang $100 \%$ sesuai terhadap Formularium Kabupaten Banjar periode 2019. Adapun persentase rerata peresepan obat di rawat jalan Puskesmas Sungai Tabuk 1 yang sesuai dengan Formularium Kabupaten Banjar periode 2019 sebesar 99,15.

\section{UCAPAN TERIMA KASIH}

Terima kasih kepada Puskesmas Sungai Tabuk 1 Kalimantan Selatan sebagai tempat penelitian. Terima kasih kepada Dewi Ratna Sari dan Sarah Regina serta pihak-pihak yang telah membantu dalam penelitian maupun penyusunan tulisan ini.

\section{DAFTAR PUSTAKA}

1. Kemenkes RI. Peraturan Menteri Kesehatan Republik Indonesia Nomor 75 tentang Pusat Kesehatan Masyarakat. Jakarta: Kementerian Kesehatan Republik Indonesia; 2014. 
2. Kemenkes RI. Permenkes Nomor 74 Tahun 2016 tentang Standar Pelayanan Kefarmasian Di Puskesmas. Jakarta: Kementerian Kesehatan Republik Indonesia; 2016.

3. Kemenkes RI. Petunjuk Teknis Standar Kefarmasian di Puskesmas. Jakarta: Kementrian Kesehatan Republik Indonesia; 2019.

4. Kemenkes RI. Permenkes Nomor 54 Tahun 2018 tentang Penyusunan dan Penerapan Formularium Nasional dalam Penyelenggaraan Program Jaminan Kesehatan. Jakarta: Kementrian Kesehatan Republik Indonesia; 2018.

5. Priyadi A, Destiani DP. Monitoring Pola Peresepan Obat Pasien Usia 0-2 Tahun Menggunakan Indikator WHO. Indonesian Journal of Clinical Pharmacy. 2013;2(1):28-32.

6. Kemenkes RI. Bahan Paparan Jaminan Kesehatan Nasional (JKN) Dalam Sistem Jaminan Sosial Nasional. Jakarta: Kementerian Kesehatan Republik Indonesia; 2013.

7. Winda SW. Formularium Nasional (FORNAS) dan e-Catalogue Obat Sebagai Upaya Pencegahan Korupsi dalam Tata Kelola Obat Jaminan Kesehatan Nasional (JKN). Integritas : Jurnal Antikorupsi. 2018;4(2):177-206.

8. Anggriani Y, Pudjaningsih D, Suryawati D. Pengaruh Proses Pengembangan dan Revisi Formularium Rumah Sakit terhadap Pengadaan dan Stok Obat. JURNAL ILMU KEFARMASIAN
INDONESIA. 2008 Apr 30;6(1):419.

9. Siregar. Farmasi Rumah Sakit: Teori \& Penerapan. Jakarta: EGC; 2004.

10. Pratiwi WR, Kautsar AP, Gozali D. Hubungan Kesesuaian Penulisan Resep dengan Formularium Nasional Terhadap Mutu Pelayanan pada Pasien Jaminan Kesehatan Nasional di Rumah Sakit Umum di Bandung. Pharmaceutical Sciences and Research (PSR). 2017;4(1):48-5656.

11. Prayitno L, Yuniar Y, Rosita T. Kesesuaian Antara Ketersediaan Antibiotik dan Formularium Nasional Pada Era JKN di Faskes Tingkat Pertama Kota Manado Tahun 2014 2017. Buletin Penelitian Kesehatan. 2020;48(1).

12. Dinkes Kabupaten Banjar. Formularium Obat pada Fasilitas Tingkat Pertama (Puskesmas) Dinas Kesehatan Kabupaten Banjar. Martapura, Kal-Sel: Dinas Kesehatan Kabupaten Banjar; 2019.

13. Kartikasari K, Hapsari I, Kusuma AM. Pengaruh Kepatuhan Dokter Dalam Penulisan Resep Sesuai Formularium Obat Golongan Antibiotik Terhadap Obat Macet Golongan Antibiotik Di Rumah Sakit Umum Purbalingga Periode JanuariJuni 2011. PHARMACY: Jurnal Farmasi Indonesia (Pharmaceutical Journal of Indonesia). 2012;9(02).

14. Lestari T, Anggriani Y, Laksmitawati DR. Analisa Kesesuaian Peresepan Obat Pasien BPJS Kesehatan Dengan 
Formularium Nasional Di Puskesmas

Kabupaten Tangerang Tahun 2016. Jurnal Farmagazine. 2019 Aug 1;6(2):57-65.

15. Prihandiwati E, Hiliyanti $\mathrm{H}$, Waty A. Kesesuaian Peresepan Obat Pasien BPJS Kesehatan Dengan Formularium Nasional Di RSD Idaman Kota Banjarbaru. 1. 2018;1(2):184-90.

16. Arfania M, Ernawati E. Analisis Kesesuaian Penulisan Resep Pasien Jantung Berdasarkan Formularium Nasional Dan E-Catalogue Di Rumah Sakit Karawang. Pharma Xplore: Jurnal Ilmiah Farmasi. 2020;5(1):17.

17. Rahmawati F, Rakhmawatie MD, Indrastiti R. Efektivitas Pengobatan Kombinasi RifampisinKlaritromisin dengan MDT WHO terhadap Derajat Kesembuhan Pasien Lepra Tipe PB. Jurnal Kedokteran Muhammadiyah. 2014;3(2).

18. Qonita H. Perbandingan Efektivitas Terapi Kombinasi Salep 3-6 dan Sabun Sulfur 10\% dengan Salep 3-6 Tunggal pada Pengobatan Skabies Di Pondok Pesantren Ummul Qura [Skripsi]. [Jakarta]: Universitas Islam Negeri Syarif Hidayatullah; 2015.

19. Medisa D, Danu SS, Rustamaji R. Kesesuaian Resep Dengan Standar Pelayanan Medis Dan Formularium Jamkesmas Pada Pasien Rawat Jalan Jamkesmas. Jurnal Ilmiah Farmasi. 2015;11(1):20-8.

20. Mahfudhoh S, Rohmah TN. Faktor Yang Mempengaruhi
Kepatuhan Penulisan Resep Sesuai Formularium. Jurnal Administrasi Kesehatan Indonesia. 2015;3(1):2130 .

21. Vermasari A, Masrul M, Yetti H. Analisis Implementasi Standar Pelayanan Minimal (SPM) Di Instalasi Gawat Darurat (IGD) Rsu Mayjen Ha Thalib Kabupaten Kerinci. Jurnal Kesehatan Andalas. 2019 May 14;8(2):275-84.

22. Sari VM, Pratiwi Y. Prosentase Pelaksanaan Obat Antibiotik Oral Sesuai dengan Formularium Rumah Sakit Pada Pasien BPJS Rawat Jalan di RSUD dr. Loekmono Hadi Kudus. Jurnal Keperawatan dan Kesehatan Masyarakat Cendekia Utama. 2017;5(2).

23. Kemenkes RI. Standar Teknis Pemenuhan Mutu Pelayanan Dasar Pada Standar Pelayanan Minimal Bidang Kesehatan. Jakarta: Kementerian Kesehatan Republik Indonesia; 2019.

24. Oktarlina RZ. Analisis FaktorFaktor Motivasi dan Persepsi yang Mempengaruhi Penulisan Resep sesuai Formularium di Instalasi Rawat Jalan RSUP Dr. M. Djamil, Padang. Jurnal Agromedicine. 2016 Feb 1;3(1):13-8. 